\title{
ANALISA PERBANDINGAN HARAPAN DAN PERSEPSI PRIA DAN WANITA DALAM MEMILIH SEBUAH RESTORAN DI SURABAYA DITINJAU DARI SEGI MEAL EXPERIENCE
}

\author{
Priska Vianny Marsellita \& Veranita Goenawan \\ Alumni Program Manajemen Perhotelan, Fakultas Ekonomi, Unversitas Kristen Petra \\ Zeplin Jiwa Husada Tarigan \\ Fakultas Ekonomi, Universitas Kristen Petra \\ e-mail: zeplin@petra.ac.id \\ Monika Kristanti \\ Program Manajemen Perhotelan, Fakultas Ekonomi, Universitas Kristen Petra \\ e-mail: mkrist@peter.petra.ac.id
}

\begin{abstract}
Abstrak: Pria dan wanita memiliki sifat dan karakteristik yang berbeda, sehingga dapat menimbulkan harapan yang berbeda terhadap pemilihan restoran. Penelitian ini bertujuan mengetahui apakah terdapat perbedaan harapan antara pria dan wanita dalam memilih sebuah restoran di Surabaya ditinjau dari segi meal experience, mengetahui faktor yang paling dominan berpengaruh, serta bertujuan mengukur apakah ada gap antara harapan dan persepsi konsumen. Hasil penelitian menunjukkan bahwa pria dan wanita memiliki harapan yang berbeda untuk faktor suasana, dan ditemukan pula bahwa terjadi gap antara harapan dan persepsi konsumen.
\end{abstract}

Kata kunci: harapan, persepsi, pria, wanita, restoran, meal experience

\begin{abstract}
Men and women have different behavior and characteristics that can affect their expectation in choosing the restaurant. This research was conducted to examine whether meal experience at restaurant will affect the expectation of men and women when choosing restaurant at Surabaya, the most dominant factors and if there is gap between expectation and perception. The result showed that men and women have different expectation in term of atmosphere and there is gap between expectation and perception.
\end{abstract}

Keywords: Expectation, perception, man, woman, restaurant, meal experience

Menurut Davis, Lockwood, Pantelidis, dan Alcott (2008) restoran dapat dinilai dari: makanan, business, social, location and accessibility, service, cleanliness and hygiene, atmosphere dan harga. Penilaian bagus tidaknya sebuah restoran tidak berkutat hanya pada kualitas ataupun kuantitas makanan saja. Faktor-faktor penentu nilai bagus tidaknya sebuah restoran tersebut dinamakan dengan meal experience. Penilaian meal experience dapat dilakukan oleh setiap konsumen, baik pria maupun wanita, dimana keduanya mempunyai sifat dan karakteristik yang berbeda.

Pada penelitian yang dilakukan oleh Butchal dari New American Diner Study (NADS) pada tahun 2005 dalam jurnalnya Food Battle of the sexes, menunjukan adanya perbedaan perilaku pria dan wanita saat makan dalam sebuah restoran yang dapat dilihat pada tabel 1 . Dari perbedaan perilaku yang ada antara pria dan wanita, tampak bahwa harapan pria dan wanita dalam memilih restoran pun juga berbeda.
Tabel 1. Perbedaan perilaku pria dan wanita saat makan di restoran

\begin{tabular}{lcc}
\hline & Pria & Wanita \\
\hline $\begin{array}{l}\text { Porsi yang terlalu banyak } \\
\begin{array}{l}\text { Membawa pulang makanan ke } \\
\text { rumah (take away) }\end{array}\end{array}$ & $39 \%$ & $63 \%$ \\
$\begin{array}{l}\text { Menggunakan kartu kredit } \\
\text { sebagai alat pembayaran }\end{array}$ & $55.9 \%$ & $45 \%$ \\
$\begin{array}{l}\text { Lebih mengutamakan } \\
\text { independent restaurant daripada } \\
\text { chain restaurant }\end{array}$ & $43.6 \%$ & $37.6 \%$ \\
Berbagi makanan & $26.1 \%$ & $43.6 \%$ \\
\hline
\end{tabular}

Sumber: Buchtal (2005, p.17)

Penelitian ini juga diperkuat oleh survei awal yang dilakukan oleh peneliti terhadap 10 pria dan 10 wanita mengenai alasan utama pria dan wanita makan 
di restoran. Hasilnya menunjukkan bahwa faktor utama yang mempengaruhi pria dalam memilih restoran adalah rasa serta harga makanan, sedangkan bagi wanita yang terpenting adalah suasana, kebersihan dan makanan.

Selain itu, dalam artikel "Old Gender Roles with Your Dinner" oleh Bruni (2008), The New York Times juga ditemukan beberapa perbedaan harapan wanita dan pria dalam memilih sebuah restoran. Wanita cenderung lebih memilih restoran yang nyaman, sedangkan pria mencari restoran dimana pria bisa mendapatkan prestige yang lebih tinggi. Berdasarkan wawancara terhadap beberapa pemilik restoran dan pramusaji, diketahui bahwa pria lebih suka disapa dengan tidak berlebihan dan diperlakukan seperti orang dalam (insider). Wanita lebih melindungi diri (lebih suka berlaku sebagai outsider). Dalam memilih sebuah restoran, wanita juga sangat memperhatikan kebersihan restroom dan sangat menyukai permainan desain restoran. Sedangkan pria kurang memperhatikan hal-hal seperti itu. "Men spend more and women spend less," said Steve Dublanica, author of bestseller "Waiter Rant". In addition, he said: "Men eat and leave. Women eat and stick around." Pria mengkonsumsi lebih banyak dan membayar lebih banyak dari pada wanita. Jika pria memiliki kebiasaan untuk segera pergi setelah makan, wanita berlaku sebaliknya. Wanita lebih suka untuk berbincang-bincang setelah makan. Dari artikel ini, Bruni menunjukkan bahwa terdapat perbedaan harapan pria dan wanita dalam memilih sebuah restoran.

Harapan yang ada, baik dalam diri pria maupun wanita, adalah sesuatu yang seharusnya dapat dipenuhi oleh penyedia barang dan jasa manapun, dimana nantinya dapat membawa dampak yang baik bagi para penyedia jasa. Namun sampai saat ini masih banyak restoran yang belum bisa memberikan persepsi atau kenyataan pelayanan kepada konsumen yang sesuai dengan harapan konsumen. Hal-hal yang telah dibahas ini memberikan inspirasi kepada penulis untuk mengidentifikasi harapan wanita dan pria serta menilai apakah kenyataan yang ada dalam restoran telah sesuai dengan harapan konsumen, sehingga bermanfaat bagi pengembangan restoran di masa yang akan datang.

\section{TEORI PENUNJANG}

\section{Definisi Harapan}

Menurut Lovelock, Patterson, dan Walker (2001, p. 91), "harapan konsumen adalah keyakinan seseorang tentang pelayanan yang akan diterima pada saat orang tersebut melakukan transaksi, sebagai tolak ukur sebelum mengambil keputusan”. Dalam memahami harapan konsumen, restoran harus lebih dulu memahami tentang jenis-jenis harapan serta harapan konsumen pada umumnya.

\section{Konsep Pria dan Wanita}

Pria adalah manusia yang diciptakan dengan kemampuan fisik dan otot yang lebih besar. Umumnya pria bersifat maskulin, sedangkan wanita adalah manusia yang diciptakan dengan sensitivitas yang lebih tinggi serta bersifat feminin.

Allan dan Barbara (2007) menjelaskan pria dan wanita berbeda. Salah satunya tidak lebih buruk atau lebih baik daripada yang lain, tetapi berbeda. Satusatunya kesamaan di antara pria dan wanita adalah keduanya tergolong dalam spesies yang sama. Dunia pria dan wanita berbeda, termasuk nilai-nilai dan peraturan-peraturan yang pria dan wanita taati. Pria dan wanita dari budaya, kepercayaan dan ras apapun terus saling berdebat tentang pendapat, perilaku, sikap dan keyakinan pasangannya.

Menurut Allan dan Barbara (2007) pria dan wanita telah berubah secara perlahan-lahan dengan cara yang berbeda. Pria berburu sementara wanita mengumpulkan. Pria melindungi, wanita mengasuh. Sebagai akibat dari pembagian pekerjaan itu, tubuh dan otak pria dan wanita berkembang dengan cara yang berbeda. Pria dan wanita berpikir dengan cara yang berbeda, mempercayai hal-hal yang berbeda pula. Pria dan wanita memiliki perbedaan pandangan, prioritas dan kebiasaan.

Allan dan Barbara (2007) juga mengatakan bahwa wanita memiliki keterampilan penginderaan yang lebih peka daripada pria. Wanita memiliki sebuah intuisi wanita yang merupakan kemampuan wanita untuk melihat rincian kecil (detail) dan perubahan dari penampilan ataupun perilaku orang lain. Sedangkan pria hampir tidak menyadari adanya orang lain yang tinggal di rumahnya. Wanita dapat menjelaskan warna dengan cara yang lebih rinci. Seorang pria hanya akan menggunakan penggambaran dasar warna karena otak pria tidak dilengkapi dengan bagian untuk melihat rinci.

Allan dan Barbara (2007, p.191) mengatakan bahwa "pria dan wanita memahami dunia melalui pandangan yang berbeda. Seorang pria melihat hal-hal dan benda-benda serta hubungan satu sama lainnya dalam pengertian ruang seolah sedang meletakkan keping-keping puzzle dan menyatukannya menjadi sebuah gambar utuh. Sedangkan wanita secara harafiah memandang dunia sebagai gambar yang lebih besar, lebih luas dan melihat detail-detail halus. 
Namun keping-keping puzzle itu sendiri dan hubungan wanita dengan keping-keping lainnya tampak lebih terjalin daripada penempatan ruang wanita".

Seorang pria ketika berhasil melakukan tugas sebaik yang pria bayangkan, pria cenderung mengaitkan keberhasilan pria dengan ketrampilan atau kecerdasan pria. Jika yang pria lakukan tidak sesuai dengan harapan, pria cenderung menyalahkan nasib buruk atau adanya faktor lain di luar kemampuan pria. Sedangkan wanita hanya bisa mencapai harapan wanita yang rendah, wanita cenderung mengaitkannya dengan kekurangan wanita dalam hal kemampuan atau kecerdasan. Kalau wanita berhasil melampaui dugaan yang rendah untuk sukses, wanita cenderung mengaitkannya dengan keberuntungan atau faktor lain di luar jangkauan wanita. (Bill dan Farrel, 2004).

Menurut Segal, Dasen, Berry dan Portinga (1990, p. 261), "There are some tenacious difference between men and women in behavior". Terdapat perbedaan yang kuat dalam perilaku pria dan wanita. Konsumen pria adalah konsumen yang mudah dipengaruhi oleh nasehat yang baik serta argumentasi yang obyektif. Sedangkan konsumen wanita lebih banyak tertarik pada warna dan bentuk, kurang tertarik pada hal-hal teknis, lebih mementingkan status sosial, lebih peka, menyenangi hal-hal yang romantis daripada obyektif, mudah meminta pandangan, pendapat maupun nasehat dari orang lain. Sehingga merupakan suatu kesalahan jika para penyedia produk dan jasa memperlakukan wanita sama layaknya dengan pria dan sebaliknya.

Menurut Kartajaya (2003, p.24) "wanita selalu memperhatikan hingga ke detail. Konsumen wanita akan menilai segala sesuatu dengan lebih terperinci. Sehingga jangan sampai para penyedia jasa (yang dimaksud dalam tugas akhir ini adalah: restoran) melupakan satu hal bagian kecil saja jika tidak ingin konsumen kecewa. Konsumen wanita juga sangat awas terhadap berbagai isu. Sedangkan pria kurang memperhatikan detail dan isu yang terjadi”.

\section{Konsep Meal Experience}

Dalam memilih sebuah restoran, konsumen tidak hanya terpaku pada makanan saja tetapi juga pelayanan dan hal lain-lain dari sebuah restoran. Menurut Davis, Lockwood, Pantelidis, dan Alcott (2008), saat konsumen makan dalam sebuah restoran, konsumen akan mengalami meal experience, yang antara lain adalah:

a. Makanan \& Minuman

Makanan dan minuman yang disajikan dalam sebuah restoran dapat dinilai dari berbagai hal, antara lain:
1. Pilihan makanan dan minuman yang tersedia, apakah pilihannya terbatas atau luas dan fleksibel tidaknya dalam pemilihan menu (restoran dapat menyediakan kebutuhan khusus).

2. Kualitas makanan dan minuman yang disajikan, termasuk di dalamnya kualitas bahan masakan.

3. Kuantitas makanan dan minuman yang disajikan. Apakah restoran menyediakan porsi yang lebih kecil untuk anak-anak atau orang tua.

4. Konsistensi standard dari makanan dan minuman yang disajikan.

5. Batasan rasa, tekstur, aroma dan warna (penampilan) pada makanan dan minuman yang disajikan.

6. Makanan dan minuman yang ada disajikan pada suhu yang sesuai.

7. Bentuk penyajian makanan dan minuman yang menguatkan penilaian dalam penyajian produk. Hal ini dinilai cukup penting karena penyajian visual mengambil bagian yang cukup besar dalam meal experience.

b. Pelayanan

Pelayanan dalam sebuah restoran juga merupakan bahan pertimbangan bagi seseorang untuk memilih restoran tersebut. Semakin tinggi biaya yang dikeluarkan oleh konsumen, semakin besar harapan akan pelayanan yang berkualitas. Sangat penting bagi restoran untuk menentukan standar pelayanan. Penilaian pelayanan dapat dilihat dari hal-hal di bawah ini:

1. kecepatan pelayanan,

2. penampilan karyawan,

3. fasilitas restoran, contoh akses internet,

4. tamu di anggap sebagai sebuah pribadi (dihargai dan dihormati), dan

5. kenyamanan yang diterima oleh konsumen (apakah konsumen merasa nyaman dengan pelayanan yang ada atau tidak).

Menurut Cousines, Foskett, dan Gillespie (2002, p.14) Tingkat pelayanan selain dari faktor-faktor di atas dapat juga dinilai dari: ketersediaan fasilitas untuk memesan tempat, serta adanya fasilitas untuk menggunakan kartu kredit sebagai alat pembayaran.

c. Cleanliness and Hygiene

Masalah kebersihan adalah penilaian yang cukup penting bagi konsumen. Penilaian cleanliness and hygiene dapat dinilai dari:

1. kebersihan fasilitas yang ada dalam restoran,

2. kebersihan alat yang digunakan untuk memasak, 
3. kebersihan dapur restoran (meskipun kurang tampak oleh tamu),

4. kebersihan peralatan makan atau peralatan yang digunakan untuk menyajikan makanan, dan

5. kebersihan lingkungan restoran itu sendiri.

d. Suasana

Suasana dalam sebuah restoran terbentuk dari halhal di bawah ini:

1. Dekorasi dan desain interior

Pandangan pertama pada sebuah restoran adalah hal yang sangat penting. Potential customers sering melihat penampilan sebuah restoran sebelum konsumen menentukan akan makan dimana. Dekorasi dari sebuah restoran seharusnya membuat konsumen merasa nyaman. Desain interior sendiri mencakup banyak hal, antara lain: ukuran dan bentuk ruangan, perabotan dan penempatan, pemilihan warna, pencahayaan, pendingin udara, dan lain-lain. Jika konsumen membayar mahal, konsumen akan berharap lebih mengenai dekorasi ruangan. Sangat tidak mungkin jika fine dining restaurant didekorasi layaknya theme restaurant, dan begitu pula sebaliknya.

2. Pengaturan meja dan tempat duduk

Penataan meja serta kursi sebaiknya tidak telalu berdesakan satu dengan yang lain. Diperlukan cukup ruang, baik bagi karyawan maupun konsumen untuk berlalulalang secara bebas tanpa mengganggu konsumen yang lain.

3. Pelayanan tambahan

Pelayanan tambahan adalah pelayanan lebih yang diberikan oleh penyedia jasa restoran untuk meningkatkan kepuasan tamu. Contohnya: saat tamu berulangtahun, penyedia jasa restoran memberikan kue ulangtahun sebagai kejutan atau sebagai compliment.

4. Umur, penampilan dan jenis kelamin pelanggan lain

Umur, penampilan dan jenis kelamin pelanggan lain akan memberikan pengaruh bagi konsumen. Contoh: jika ada tamu yang sedang berbicara masalah bisnis dalam sebuah restoran, dan di meja dekat tamu tersebut terdapat tamu seperti anak-anak kuliah, SMP atau SMA yang cenderung ramai, maka tamu tersebut akan kurang nyaman.

5. Tingkat suara di dalam restoran

Besar kecilnya musik serta tingkat keramaian yang ada dalam sebuah restoran.

6. Suhu ruang

Umumnya jika suhu ruang makin panas, konsumen akan cenderung lebih mudah marah atau merasa tidak nyaman.
7. Keselarasan antara produk itu sendiri, pelayanan dan lingkungan secara keseluruhan

Seandainya restoran tersebut mengusung tema Jepang, maka produk makanan yang dibuat seharusnya bertemakan Jepang, nuansa restoran juga bersifat Jepang, dan pelayanan juga berbau Jepang. Contoh: dalam menyampaikan salam menggunakan bahasa Jepang seperti "youkosso, itterasai", dan lain sebagainya.

Selain penilaian dari hal-hal di atas Cousines, Foskett, dan Gillespie (2002, p.14) menambahkan bahwa: tingkat kebisingan, pelanggan lain, karyawan dan sikap serta pengetahuan karyawan yang memadai tentang menu juga menentukan suasana sebuah restoran.

e. Harga dan nilai uang

Bukan hanya makanan dan pelayanan saja yang dilihat oleh konsumen dalam memilih sebuah restoran, tetapi konsumen juga melihat harga. Restoran akhir-akhir ini banyak memberikan "meal deal" (seperti harga paket sehingga harga yang ditawarkan menjadi lebih murah).

Harga sendiri berarti nilai suatu barang atau jasa yang diukur dengan sejumlah uang dimana berdasarkan nilai tersebut, seseorang atau perusahaan bersedia melepaskan barang atau jasa yang dimiliki kepada pihak lain. Nitisemito (1993, p.55) Konsumen yang ada akan melihat apakah harga yang konsumen bayar sesuai dengan apa yang konsumen terima.

Dalam bukunya, Cousines, Foskett, dan Gillespie (2002, p.14) menyebut faktor ini sebagai: perceived value for money and price dimana konsumen melihat apakah sesuai pengeluaran konsumen dengan jenis restoran serta pelayanan yang konsumen terima.

\section{Konsep Persepsi}

Persepsi adalah pandangan terhadap pelayanan yang telah diterima oleh konsumen. Sangat memungkinkan bahwa persepsi konsumen tentang pelayanan menjadi berbeda dari kenyataannya karena konsumen tidak mengetahui semua fakta yang ada atau telah salah dalam menginterpretasikan faktor tersebut. Persepsi dari suatu pelayanan sangat dipengaruhi oleh proses dalam memberikan pelayanan dan juga hasil dari memberikan pelayanan (Hill, 1992, p.44).

Horovitz (2000, p.4) mengatakan bahwa "persepsi adalah anggapan yang muncul setelah melakukan pengamatan di lingkungan sekitar atau melihat situasi yang terjadi untuk mendapatkan informasi tentang sesuatu". "Persepsi masing-masing individu terhadap satu situasi yang sama bisa berbeda- 


\section{Kerangka Pemikiran}

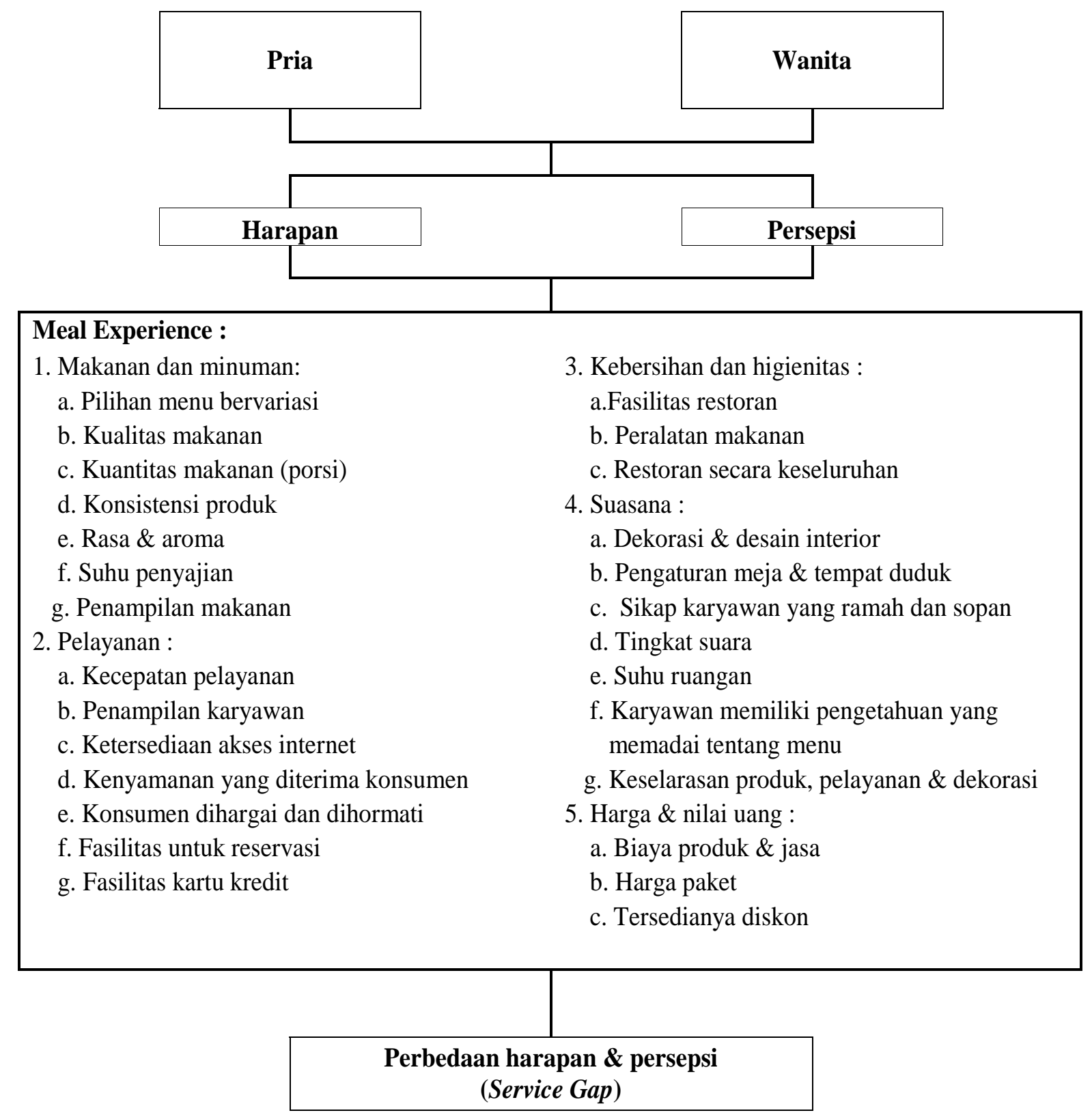

Sumber : Davis, Lockwood, Pantelidis dan Alcott (2008, pp. 30-38)

\section{Gambar 1. Kerangka pemikiran}

beda. Hal ini disebabkan karena setiap orang menerima, mengorganisasi, dan menerjemahkan informasi dengan caranya masing-masing" (Bowen, Kotler \& Makens, 1999, p.196).

\section{Hipotesis}

1. Berdasarkan hasil penelitian yang dilakukan oleh New American Diner Study (NADS) pada tahun 2005 dalam jurnalnya Food Battle of the Sexes, penulis menduga bahwa terdapat perbedaan yang signifikan antara harapan pria dan wanita dalam memilih sebuah restoran di Surabaya dari segi meal experience.

2. Restoran merupakan penyedia jasa dan produk berupa makanan, maka penulis menduga bahwa setiap konsumen akan memilih sebuah restoran karena kualitas makanan yang disediakan.

3. Penulis menduga bahwa terdapat gap antara harapan dan persepsi konsumen. 


\section{METODE PENELITIAN}

\section{Jenis Penelitian, Populasi dan Sampel}

Jenis penelitian adalah penelitian kuantitatif deskriptif, yang bertujuan melihat apakah ada perbedaan harapan antara pria dan wanita dalam pemilihan sebuah restoran ditinjau dari segi meal experience.

Populasi dalam penelitian ini adalah pria dan wanita yang berusia 21-50 tahun dengan pendapatan rata-rata tiap bulan di atas Rp. 1.500.000,-. Pria dan wanita yang menjadi responden dalam penelitian ini, minimal pernah makan di family restaurant di Surabaya dalam tiga bulan terakhir.

Metode pengambilan sampel yang digunakan adalah non probability sampling, sedangkan teknik pengambilan sampel yang digunakan adalah kombinasi dari quota sampling - karena penulis menetapkan untuk membagi quota sampel menjadi $50 \%$ untuk kelompok responden pria dan 50\% untuk kelompok responden wanita -, serta judgemental sampling - karena penulis memilih anggota sampel berdasarkan kriteria-kriteria yang sudah ditetapkan, antara lain berusia 21-50 tahun, memiliki pemasukan di atas Rp. 1.500.000,- serta dalam tiga bulan terakhir (Agustus, September, Oktober 2009) minimal pernah makan di family restaurant di Surabaya (contoh: Penang's House, Qua-Li, Jade Imperial, XO Chinese Cuisine, XO Suki, Ayam Bakar Primarasa, Ikan Bakar Cianjur, Boncafe, Fu Yuan, The Duck King, dil). Penulis mengambil 200 sampel yang akan dibagikan sama rata, yaitu 100 kuesioner untuk pria dan 100 kuesioner untuk wanita.

\section{Variabel dan Definisi Operasional Variabel}

1. Harapan

Harapan konsumen adalah keyakinan konsumen tentang produk serta pelayanan dari restoran yang akan dipilih.

2. Meal Experience

a. Makanan

Makanan dan minuman yang disajikan dalam sebuah restoran, yang nantinya dinilai dari:

1. Pilihan makanan dan minuman yang tersedia, apakah pilihannya terbatas atau luas dan fleksibel tidaknya dalam pemilihan menu (restoran dapat menyediakan kebutuhan khusus).

2. Kualitas makanan dan minuman yang disajikan, termasuk di dalamnya kualitas bahan masakan.
3. Kuantitas makanan dan minuman yang disajikan. Apakah restoran menyediakan porsi yang lebih kecil untuk anak-anak atau orang tua.

4. Konsistensi standard dari makanan dan minuman yang disajikan.

5. Batasan rasa, tekstur, aroma dan warna (penampilan) pada makanan dan minuman yang disajikan.

6. Makanan dan minuman yang ada disajikan pada suhu yang sesuai.

7. Bentuk penyajian makanan dan minuman yang menguatkan penilaian dalam penyajian produk. Hal ini dinilai cukup penting karena penyajian visual mengambil bagian yang cukup besar dalam meal experience.

b. Pelayanan

Pelayanan dalam restoran yang dikunjungi dapat dinilai dari:

1. kecepatan pelayanan

2. penampilan karyawan

3. fasilitas restoran, contoh akses internet

4. tamu di anggap sebagai sebuah pribadi (dihargai dan dihormati)

5. kenyamanan yang diterima oleh konsumen (apakah konsumen merasa nyaman dengan pelayanan yang ada atau tidak)

6. ketersediaan fasilitas untuk reservasi

7. adanya fasilitas untuk menggunakan kartu kredit sebagai alat pembayaran.

c. Cleanliness and Hygiene

Mencakup masalah kebersihan dalam sebuah restoran yang dapat dinilai oleh konsumen secara langsung, yaitu:

1. toilet yang ada dalam restoran bersih dan tidak bau,

2. peralatan makan yang digunakan bersih, dan

3. kebersihan lingkungan restoran itu sendiri.

d. Suasana

Suasana dalam sebuah restoran terbentuk dari hal-hal di bawah ini:

1. dekorasi dan desain interior yang menarik

2. pengaturan meja dan tempat duduk yang sesuai

3. sikap karyawan yang ramah dan sopan

4. tingkat suara yang sesuai dalam restoran

5. suhu ruangan yang sesuai

6. karyawan memiliki pengetahuan yang memadai tentang menu

7. keserasian antara produk, pelayanan dan dekorasi. 
e. Harga dan Nilai Uang

Penilaian faktor harga dalam sebuah restoran dalam penelitian ini akan dinilai dari:

1. harga sesuai dengan produk dan jasa yang diterima,

2. tersedianya harga paket,

3. tersedianya diskon atau potongan harga.

3. Persepsi konsumen

Persepsi konsumen terhadap produk dan pelayanan dalam restoran yang konsumen kunjungi akan dilihat dari masing-masing segi meal experience (poin $2 \mathrm{a}-\mathrm{e}$ ), sehingga nantinya akan dapat dibandingkan apakah persepsi konsumen sesuai dengan harapan atau tidak.

\section{Teknik Analisa Data}

1. Paired Sample T-Test digunakan untuk mengetahui berapa besar perbedaan antara harapan dan persepsi dari pria dan wanita dalam memilih sebuah restoran dari segi meal experience.

2. Evaluasi goodness of fit model PLS. Pada tahap ini dilakukan pengujian terhadap kesesuaian model melalui berbagai kriteria goodness-of-fit. Model pengukuran atau outer model dengan indikator refleksif dievaluasi dengan convergent dan discriminant validity dari indikatornya dan composite realibility untuk blok indikator. Sedangkan outer model dengan indikator formatif dievaluasi berdasarkan pada substantive contentnya yaitu dengan membandingkan besarnya relative weight dan melihat signifikansi dari ukuran weight tersebut (Solimun, 2007). Model struktural atau inner model dievaluasi dengan melihat persentase varian yang dijelaskan yaitu dengan melihat $\mathrm{R}^{2}$ (R-square variabel eksogen) untuk konstruk laten dependen dengan menggunakan ukuran Stone-Geisser Q Square test dan juga melihat besarnya koefisien jalur strukturalnya. Stabilitas dari estimasi ini dievaluasi dengan menggunakan uji t-statistik yang didapat lewat prosedur bootstrapping.

\section{ANALISIS DAN PEMBAHASAN}

\section{Analisa Demografis Responden}

Diketahui bahwa sebagian besar responden $43,5 \%$ berada dalam interval usia kategori 21-25 tahun, belum menikah $61,5 \%$, pendidikan terakhir yang dimiliki oleh responden sebagian besar adalah sarjana, dan merupakan karyawan perusahaan. Separuh responden memiliki pendapatan rata-rata per bulan yang berkisar antara Rp. 1.500.000,- hingga Rp. 2.500.000,--

\section{Analisa Paired Sample T-Test}

Tabel 2. Hasil two-paired t-test faktor makanan

Paired Samples Correlations

\begin{tabular}{rccc}
\hline & N & Correlation & Sig. \\
\hline $\begin{array}{r}\text { Pair 1 Makanan untuk pria \& } \\
\text { Makanan untuk wanita }\end{array}$ & 100 & .148 & .141 \\
\hline
\end{tabular}

Dari tabel di atas dapat dilihat bahwa nilai sig value $=0,141>0,1$ maka: $\mathrm{H}_{1 \text { (maknan) }}$ - harapan pria dan wanita dalam memilih sebuah restoran dari segi makanan berbeda signifikan - tidak dapat diterima. Hal ini berarti harapan pria dan wanita dalam memilih sebuah restoran dari segi makanan tidak berbeda signifikan.

\section{Tabel 3. Hasil two-paired t-test faktor pelayanan}

Paired Samples Correlations

\begin{tabular}{cccc}
\hline & $\mathbf{N}$ & Correlation & Sig. \\
\hline Pair 1 & Pelayanan untuk pria \& \\
$\begin{array}{c}\text { Pelayanan untuk wanita } \\
100\end{array}$ & .035 & .728 \\
\hline
\end{tabular}

Nilai sig. value $=0,728>0,1$ maka: hipotesa penulis tentang "Harapan pria dan wanita dalam memilih sebuah restoran dari segi pelayanan berbeda signifikan" tidak dapat diterima. Hal ini berarti bahwa tidak ada perbedaan yang signifikan antara harapan pria dan wanita dalam faktor pelayanan.

\begin{tabular}{|c|c|c|c|c|}
\hline \multirow{2}{*}{ bel 4.} & \multicolumn{4}{|c|}{$\begin{array}{l}\text { Hasil two-paired t-test fakto } \\
\text { and hygiene } \\
\quad \text { Paired Samples Correlations }\end{array}$} \\
\hline & & $\mathbf{N}$ & Correlation & Sig. \\
\hline air 1 & $\begin{array}{l}\text { \&H untuk } p \\
\& \mathrm{H} \text { untuk } \mathrm{p}\end{array}$ & 100 & .131 & .195 \\
\hline
\end{tabular}

Nilai sig value $=0,195>0,1$ maka: $\mathrm{H}_{1 \text { (cleanliness and }}$ hygiene) - harapan pria dan wanita dalam memilih sebuah restoran dari segi cleanliness and hygiene berbeda signifikan - tidak dapat diterima. Hal ini berarti tidak ada perbedaan yang signifikan antara harapan pria dan wanita dalam memilih sebuah restoran dari segi cleanliness and hygiene.

\section{Tabel 5. Hasil two paired t-test faktor suasana}

Paired Samples Correlations

\begin{tabular}{ccccc}
\hline & & N & Correlation & Sig. \\
\hline Pair 1 & $\begin{array}{c}\text { Suasana untuk pria \& } \\
\text { Suasana untuk wanita }\end{array}$ & 100 & .193 & .055 \\
\hline
\end{tabular}


Nilai sig value $=0.055<0,1$ maka: $\mathrm{H}_{1 \text { (suasana) }}-$ harapan pria dan wanita dalam memilih sebuah restoran dari segi suasana berbeda signifikan - dapat diterima.

\section{Tabel 6. Hasil two paired t-test faktor harga}

\begin{tabular}{rccc}
\hline \multicolumn{4}{c}{ Paired Samples Correlations } \\
\hline & N & Correlation & Sig. \\
\hline Pair 1 Harga untuk pria \& & 100 & .080 & .427 \\
\hline
\end{tabular}

Nilai sig value pada faktor harga $=0.427>0,1$ maka: $\mathrm{H}_{\mathrm{o}(\mathrm{harga})}$ - harapan pria dan wanita dalam memilih sebuah restoran dari segi harga berbeda signifikan - tidak dapat diterima.

\section{Analisa PLS}

Dengan menggunakan sistem "Smart PLS", penulis melakukan penghitungan pada masing-masing harapan pria dan harapan wanita untuk dapat mengetahui faktor meal experience yang paling dominan mempengaruhi harapan pria dan wanita dalam memilih sebuah restoran. Faktor meal experience yang paling dominan mempengaruhi pria maupun wanita dalam memilih sebuah restoran adalah faktor makanan. Hal tersebut dapat dilihat pada Gambar 2 dan Gambar 3.

Urutan pengaruh faktor meal experience dari yang paling besar hingga paling kecil pada pria adalah: makanan, pelayanan, suasana, harga dan cleanliness and hygiene. Sedangkan pada wanita: makanan, suasana, pelayanan, harga dan cleanliness and hygiene. Hanya terdapat perbedaan pada faktor suasana dan pelayanan. Hal tersebut dapat dilihat pada Table 7.

Tabel 7. Hasil Penghitungan Pengaruh Faktor Meal Experience pada Harapan Pria dan Wanita

\begin{tabular}{ccc}
\hline Variabel & Pria & Wanita \\
\hline Makanan & 0.381 & 0.411 \\
Pelayanan & 0.299 & 0.266 \\
Cleanliness \& Hygiene & 0.107 & 0.111 \\
Suasana & 0.281 & 0.293 \\
Harga & 0.159 & 0.153 \\
\hline
\end{tabular}

\section{Analisa Gap Harapan dan Persepsi antara Pria dan Wanita}

Dibawah ini merupakan tabel yang menggambarkan harapan dan kenyataan antara pria dan wanita.
Tabel 8. Gap Harapan dan Kenyataan Pria dan Wanita

\begin{tabular}{|c|c|c|c|c|c|c|}
\hline \multirow[b]{2}{*}{$\begin{array}{c}\text { Meal } \\
\text { Experience }\end{array}$} & \multicolumn{3}{|c|}{ Pria } & \multicolumn{3}{|c|}{ Wanita } \\
\hline & $\begin{array}{c}\text { Harap- } \\
\text { an }\end{array}$ & $\begin{array}{c}\text { Kenya- } \\
\text { taan }\end{array}$ & Gap & $\begin{array}{c}\text { Harap- } \\
\text { an }\end{array}$ & $\begin{array}{c}\text { Kenya- } \\
\text { taan }\end{array}$ & Gap \\
\hline Makanan & 4.26 & 3.47 & -0.79 & 4.27 & 3.52 & -0.75 \\
\hline Pelayanan & 4.26 & 3.43 & -0.83 & 4.28 & 3.46 & -0.82 \\
\hline $\begin{array}{l}\text { Cleanliness \& } \\
\text { Hygiene }\end{array}$ & 4.57 & 3.53 & -1.04 & 4.57 & 3.5 & -1.07 \\
\hline Suasana & 4.19 & 3.39 & -0.8 & 4.29 & 3.44 & -0.85 \\
\hline Harga & 4.28 & 3.32 & -0.96 & 4.36 & 3.32 & -1.04 \\
\hline
\end{tabular}

Berdasarkan tabel di atas, dapat diketahui bahwa dalam variabel makanan pada pria terjadi gap $-0,79$ dan pada wanita $-0,75$. Dalam variabel pelayanan, gap yang terjadi pada responden pria adalah $-0,83$ dan wanita $-0,82$. Gap yang paling besar terjadi baik pada pria maupun wanita adalah pada variabel cleanliness and hygiene. Suasana merupakan faktor pendukung yang cukup penting dalam sebuah restoran. Gap yang terjadi pada variabel suasana juga cukup besar, yaitu 0,8 untuk pria dan $-0,85$ untuk wanita. Pada variabel harga, gap yang ada pada pria adalah -0,96 dan pada wanita adalah -1,04. Gap pada variabel harga ini merupakan gap kedua terbesar setelah variabel cleanliness and hygiene.

Terjadinya gap ini menunjukkan kepada penulis, restoran serta pembaca sekalian bahwa family restaurant secara umum masih belum dapat memenuhi harapan konsumen dengan sangat baik. Penilaian rata-rata di atas 3 mengindikasikan bahwa kenyataan yang ada telah cukup memenuhi harapan konsumen, namun gap ini masih dapat diminimalisasi dengan beberapa perbaikan atau peningkatan dalam setiap faktor meal experience.

\section{Pembahasan}

Harapan Pria dan Wanita

a. Makanan

Bahwa tidak terdapat perbedaan antara wanita dan pria dari variabel makanan, hal ini dilihat dengan nilai signifikansi berada di atas $>0,1$. Hal ini menunjukkan bahwa pria dan wanita memiliki tujuan yang sama dalam memasuki sebuah restoran, yaitu mendapatkan makanan yang enak.

b. Pelayanan

Bahwa tidak terdapat perbedaan antara wanita dan pria dari variabel pelayanan, hal ini dilihat dari nilai signifikansi berada di atas $>0,1$. Hal ini menunjukkan bahwa pria dan wanita memiliki tujuan yang sama dalam memasuki sebuah restoran, pria dan wanita menginginkan pelayanan yang baik. 


\section{c. Cleanliness and Hygiene}

Bahwa tidak terdapat perbedaan antara wanita dan pria dalam hal cleanliness and hygiene, hal ini dilihat dari nilai signifikansi berada di atas $>0,1$. Hal ini menunjukkan bahwa pria dan wanita memiliki tujuan yang sama dalam memasuki sebuah restoran, yaitu tingkat kebersihan yang cukup tinggi.

d. Suasana

Bahwa terdapat perbedaan antara wanita dan pria dalam hal suasana, hal ini dilihat dari nilai signifikansi berada di bawah $<0,1$. Hal ini disebabkan wanita umumnya menyukai hal-hal yang unik, dan perhatian terhadap detail yang ada dalam sebuah restoran jauh lebih tinggi dibandingkan pria. e. Harga

Bahwa tidak terdapat perbedaan antara wanita dan pria dalam hal harga, hal ini dilihat dari nilai signifikansi berada di atas $>0,1$. Hal ini menunjukkan bahwa pria dan wanita memiliki tujuan yang sama dalam memasuki sebuah restoran, yaitu mendapatkan harga yang sesuai.

$\underline{\text { Faktor Dominan Pria dan Wanita terhadap Keseluruhan }}$

Berdasarkan dari 5 variabel yang diamati dan dianalisa pengaruhnya terhadap keseluruhan faktor pada pria didapatkan faktor yang dominan adalah faktor makanan dan sama halnya dengan wanita. Hal ini menunjukkan bahwa tujuan wanita dan pria untuk masuk ke restoran untuk menikmati makanan yang

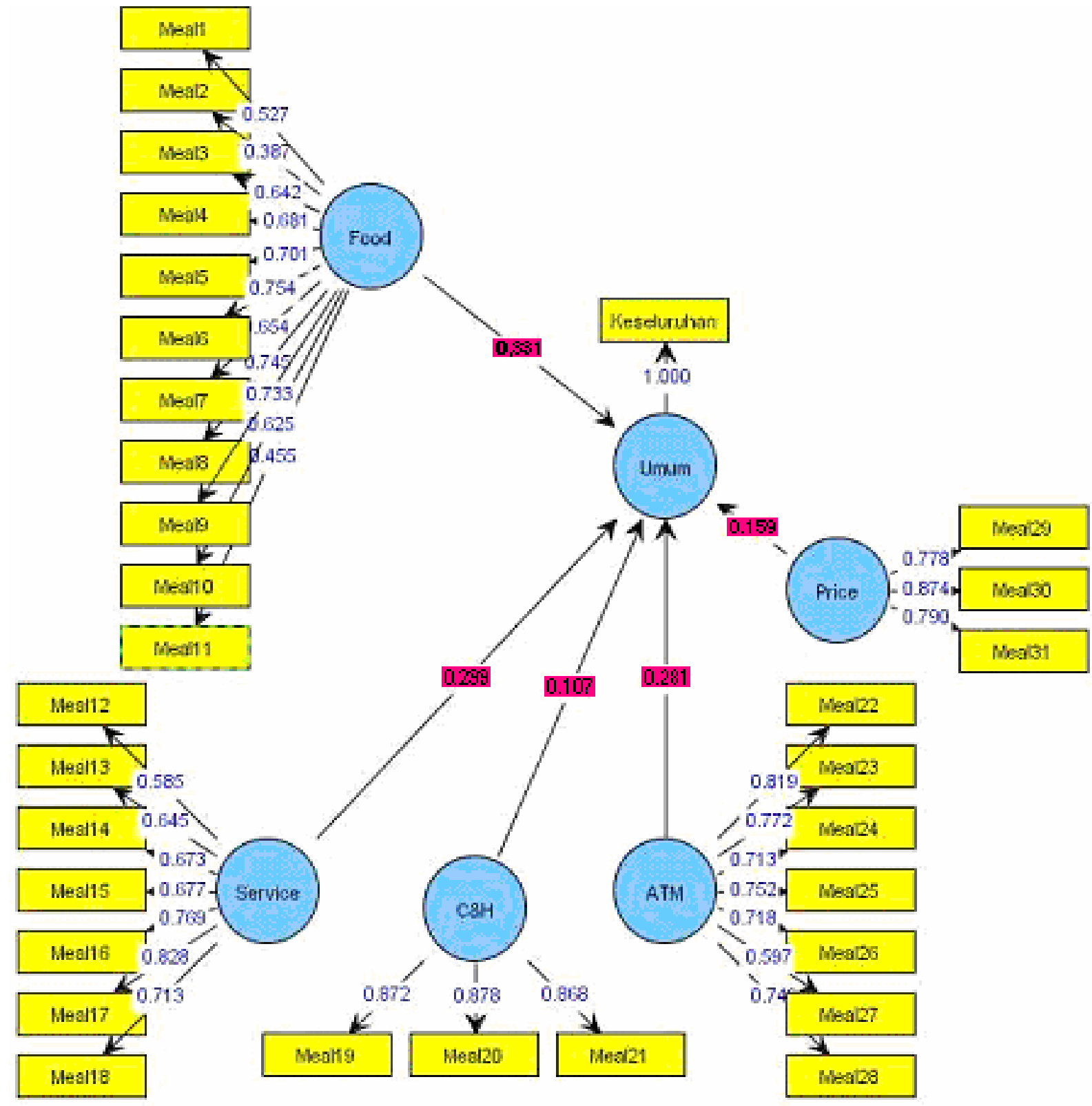

Gambar 2. Hasil Penghitungan Pengaruh Faktor Meal Experience pada Harapan Pria 


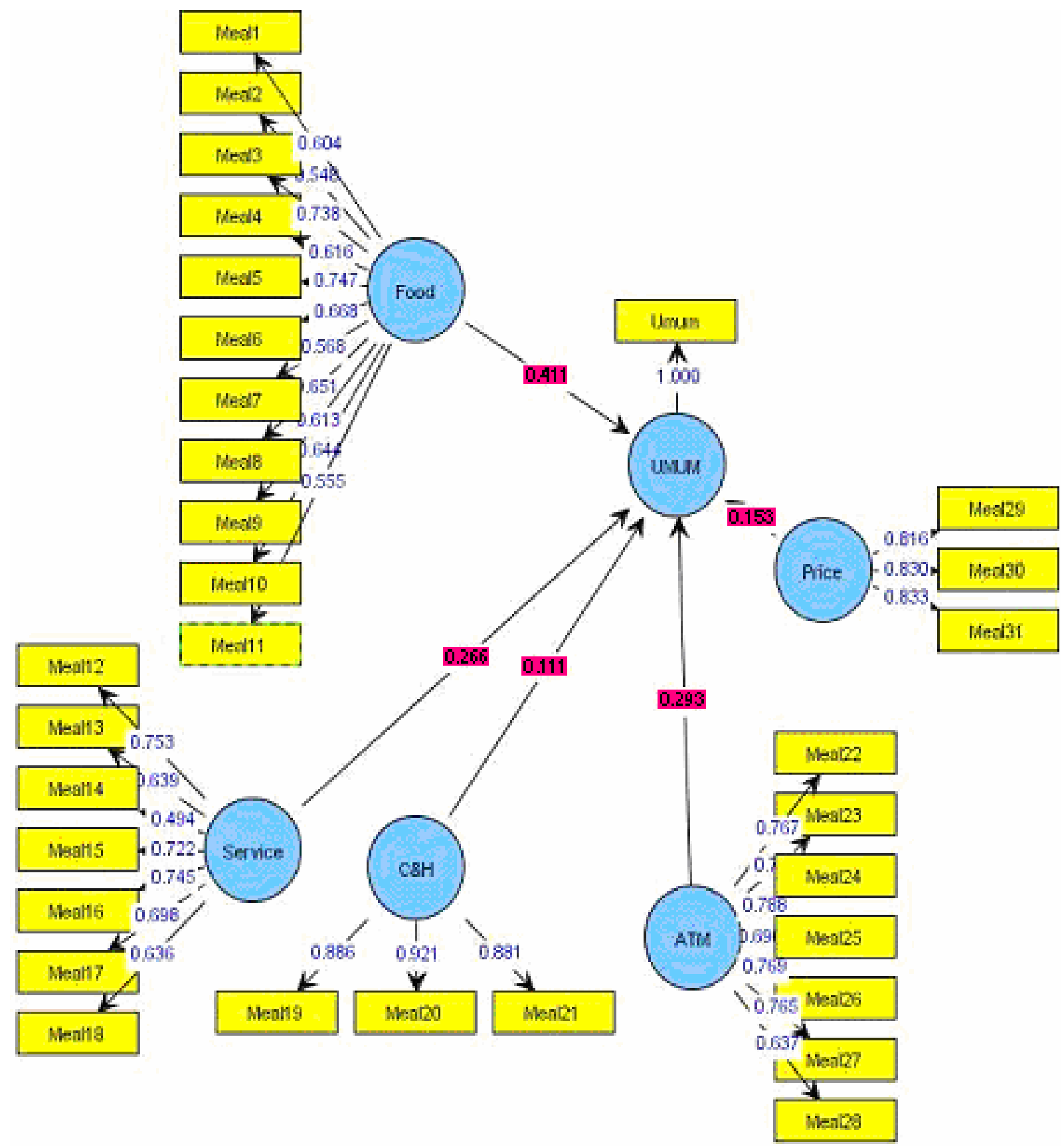

Gambar 3. Hasil Penghitungan Pengaruh Faktor Meal Experience pada Harapan Wanita

disajikan. Hal ini terkait dengan fungsi utama dari restoran.

\section{KESIMPULAN DAN SARAN}

\section{Kesimpulan}

1. Melalui two-paired t-test ANOVA yang telah dilakukan penulis, penulis menemukan bahwa harapan pria dan wanita dalam memilih sebuah restoran tidak memiliki perbedaan yang signifikan pada faktor makanan, pelayanan, cleanliness and hygiene serta harga. Hanya faktor suasana yang memiliki perbedaan signifikan.

2. Dengan menggunakan sistem "Smart PLS", penulis dapat mengetahui faktor meal experience yang paling dominan mempengaruhi pria dan wanita dalam memilih sebuah restoran adalah faktor makanan. Hal ini menunjukkan bahwa hipotesa penulis untuk rumusan masalah kedua adalah benar. 
3. Urutan pengaruh faktor meal experience dari yang paling besar hingga paling kecil pada pria adalah: makanan, pelayanan, suasana, harga dan cleanliness and hygiene. Sedangkan pada wanita: makanan, suasana, pelayanan, harga dan cleanliness and hygiene. Hanya terdapat perbedaan pada faktor suasana dan pelayanan.

4. Hasil dari analisa statistik deskriptif menunjukkan terjadi gap antara harapan dan kenyataan terhadap produk dan pelayanan restoran pada konsumen pria dan wanita. Melalui hasil ini, hipotesa penulis untuk rumusan masalah ke tiga adalah benar, adapun gap yang paling besar terlihat pada faktor kebersihan dan harga. Gap ini dapat diperkecil dengan meningkatkan mutu makanan dan minuman, pelayanan, kebersihan, suasana dan harga.

\section{Saran}

1. Melihat adanya gap yang cukup besar dalam faktor kebersihan, maka ada baiknya jika para penyedia jasa restoran lebih memperhatikan kebersihan restoran, baik itu kebersihan toilet, kebersihan peralatan makan maupun kebersihan lingkungan restoran. Untuk kebersihan toilet, karyawan dapat melakukan inspeksi kebersihan setiap satu jam atau dua jam sekali untuk tetap mempertahankan kebersihan toilet. Sedangkan untuk peralatan makan, dapat diterapkan penggunaan air hangat untuk mencuci peralatan makan, dan melakukan polishing sebelum jam operasional restoran. Mengenai kebersihan lingkungan restoran, dapat dilakukan dengan mengadakan general cleaning setiap minggu seperti yang telah dilakukan oleh restoran XO Suki dan menerapkan standar-standar sanitasi dan kebersihan yang seharusnya ditetapkan .

2. Gap terbesar kedua adalah harga. Pihak penyedia jasa makanan perlu mengetahui bahwa sudah bukan menjadi rahasia umum lagi bahwa masyarakat Indonesia merupakan masyarakat yang cukup sensitif terhadap harga sehingga ada baiknya jika para penyedia jasa makanan mengadakan kerja sama dengan kartu kredit dan mengadakan diskon ataupun harga paket dan promo pada acara-acara tertentu, seperti paket makan berdua pada saat Valentine.

3. Membuat suasana konsep yang unik, seperti: restoran yang dekat dengan alam, menambahkan dekorasi-dekorasi sesuai dengan jenis restoran, contoh: Restoran China dapat menggunakan lampion untuk semakin meningkatkan kesan oriental yang ada.

\section{DAFTAR PUSTAKA}

Arikunto, S.(1998). Manajemen penelitian. Jakarta: PT. Rineka Cipta.

Azwar, Saifuddin. (1997). Reliabilitas dan validitas. Yogyakarta: Pustaka Pelajar.

Biro Pusat Statistik. (2003). Tinjauan ekonomi kota Surabaya. Jakarta: Biro Pusat Statistik.

Bowen, J., Kotler, \& Makens, J. (1996). Marketing for hospitality and tourism ( $2^{\text {nd }}$ ed). New Jersey: Prentice Hall.

Bruni, Frank. (2008, October 8). Old Gender roles with your dinner. The New York Times,pg. 8.

Buchtal, Kristina. (2005). Food battle of the sexes. Chicago: Restaurant and Institutions.

Cousins, J., Foskett, D. \& Gillespie, C. (2002). Food and beverage management. Essex: Pearson Prentice Hall

Davis, Bernard, et. al. (2008). Food and beverage management $\left(4^{\text {th }}\right.$ edition). Butterworth Heinemann.

Farrel, Bill dan Pam.(2003). Laki-laki seperti wafer, perempuan seperti bakmi. Yogyakarta: Anak Immanuel.

Hoyer, Wayne D. \& Mac Innis, Deborah J. (1997). Consumer behaviour. Boston: Houghton Mifflin Company.

Hill, A.V. (1992). Field service management. Illinois: Richard D.Irwin.Inc.

Horovitz, J. (2000). Seven secrets of service strategy. Great Britain: Prentice Hall.

Kartajaya, H. (2003). Marketing in Venus. Jakarta: PT. Gramedia Pustaka Utama.

Kuntjara, E. (2003). Gender, bahasa dan kekuasaan. Jakarta: Gunung Mulia.

Kotler, P. (2003). Marketing management. New Jersey: Pearson Prentice Hall.

Kotler, P., \& Amstrong, J. (2004). Principles of marketing. New Jersey: Prentice Hall.

Lovelock, C.H., Patterson, P.G \& Walker, R.H. (2001). Service marketing: An Asia Pacific perspective $\left(2^{\text {nd }}\right.$ ed.). Australia: Pearson Education Australia.

Nitisemito, A.S. (1993). Marketing. Jakarta: Ghalia.

Pease, Allan \& Barbara. (2007). Why men don't listen and women can't read maps. Jakarta Selatan: Tama Printer Indonesia.

Rasubala, E. \& Prasetya, C. (2007). Analisa pengaruh harga, produk dan lokasi terhadap keputusan konsumen Cafesera Nikmat Rasa Surabaya. (TA No. 01010334/HTL/2007). Unpublished undergraduated thesis, Universitas Kristen Petra, Surabaya. 
Segall, Marshall.H, et. al.(1990). Human behaviour in global perspective: An introduction crosscultural psychology ( $1^{\text {st }}$ ed.). New Haven: Alan and Bacon.

Solimun. (2007). Bahan ajar metode kuantitatif doctoral. Malang: Universitas Brawijaya.

Tamara, K \& Natalia. (2003). Analisa pengaruh variabel harga, pelayanan, lokasi dan jenis makanan terhadap penjualan restoran Sze Cuan. (TA No.0101/044/HTL/2003). Unpublished undergraduated thesis, Universitas Kristen Petra, Surabaya.

Thamrin, V. C.(2005). Analisa perngaruh harga, produk, pelayanan, dan suasana terhadap loyalitas konsumen di restoran Hachi-Hachi
Bistro Tunjungan Plaza Surabaya. (TA No. 01010188/HTL/2005). Unpublished undergraduated thesis, Universitas Kristen Petra, Surabaya.

Walker, JR. (2004). Introduction to hospitality management. New Jersey: Pearson Prentice Hall.

Zaman, M.M. (2009). The $4^{\text {th }}$ international conference on business \& management research: Are the annual reports of public sector entities readable?. Bali:Australian Evidence.

Zeithaml, VA, A. Parasuraman \& Berry L.L. (1990). Delivering quality service: Balancing customer perceptions and expectations. New York: The Free Press. 